\title{
Last interglacial temperature seasonality reconstructed from tropical Atlantic corals
}

\author{
William M. Brocas ${ }^{\mathrm{a}, *}$, Thomas Felis ${ }^{\mathrm{a}}$, J. Christina Obert ${ }^{\mathrm{b}, \mathrm{c}}$, Paul Gierz ${ }^{\mathrm{d}}$, Gerrit Lohmann ${ }^{\mathrm{d}}$, \\ Denis Scholz ${ }^{\mathrm{b}}$, Martin Kölling ${ }^{\mathrm{a}}$, Sander R. Scheffers ${ }^{\mathrm{e}}$ \\ a MARUM - Center for Marine Environmental Sciences, University of Bremen, 28359 Bremen, Germany \\ b Institute for Geosciences, Johannes Gutenberg University Mainz, 55099 Mainz, Germany \\ c Biogeochemistry Department, Max Planck Institute for Chemistry, 55020 Mainz, Germany \\ d Alfred Wegener Institute Helmholtz Centre for Polar and Marine Research, 27570 Bremerhaven, Germany \\ e National Marine Science Centre, Southern Cross University, Coffs Harbour, NSW 2480, Australia
}

\section{A R T I C L E I N F O}

\section{Article history:}

Received 8 December 2015

Received in revised form 17 May 2016

Accepted 4 June 2016

Available online 22 June 2016

Editor: M. Frank

\section{Keywords:}

coral $\mathrm{Sr} / \mathrm{Ca}$

the last interglacial

Caribbean climate

sea surface temperature

seasonality

quasi-biennial to decadal variability

\begin{abstract}
A B S T R A C T
Reconstructions of last interglacial (LIG, MIS 5e, $\sim 127-117 \mathrm{ka}$ ) climate offer insights into the natural response and variability of the climate system during a period partially analogous to future climate change scenarios. We present well preserved fossil corals (Diploria strigosa) recovered from the southern Caribbean island of Bonaire (Caribbean Netherlands). These have been precisely dated by the ${ }^{230} \mathrm{Th} / \mathrm{U}$ method to between 130 and $120 \mathrm{ka}$ ago. Annual banding of the coral skeleton enabled construction of time windows of monthly resolved strontium/calcium $(\mathrm{Sr} / \mathrm{Ca})$ temperature proxy records. In conjunction with a previously published $118 \mathrm{ka}$ coral record, our eight records of up to 37 years in length, cover a total of 105 years within the LIG period. From these, sea surface temperature (SST) seasonality and variability in the tropical North Atlantic Ocean is reconstructed. We detect similar to modern SST seasonality of $\sim 2.9^{\circ} \mathrm{C}$ during the early (130 ka) and the late LIG (120-118 ka). However, within the mid-LIG, a significantly higher than modern SST seasonality of $4.9^{\circ} \mathrm{C}$ (at $126 \mathrm{ka}$ ) and $4.1^{\circ} \mathrm{C}$ (at $124 \mathrm{ka}$ ) is observed. These findings are supported by climate model simulations and are consistent with the evolving amplitude of orbitally induced changes in seasonality of insolation throughout the LIG, irrespective of wider climatic instabilities that characterised this period. The climate model simulations suggest that the SST seasonality changes documented in our LIG coral $\mathrm{Sr} / \mathrm{Ca}$ records are representative of larger regions within the tropical North Atlantic. These simulations also suggest that the reconstructed SST seasonality increase during the mid-LIG is caused primarily by summer warming. A 124 ka old coral documents, for the first time, evidence of decadal SST variability in the tropical North Atlantic during the LIG, akin to that observed in modern instrumental records.
\end{abstract}

(C) 2016 Elsevier B.V. All rights reserved.

\section{Introduction}

Reliable assessments of past natural climate variability are required to further evaluate the strength of modelled future climate projections, which often underestimate the extent of regional impacts (Braconnot et al., 2012). The last interglacial (LIG, Marine Isotope Stage (MIS) 5e, 127-117 ka) is often regarded as semianalogous to, and thus a test bed for, future climate change scenarios. However, warmer than present global temperatures during the LIG resulted from differing orbital configurations as opposed to increased anthropogenic emissions in recent climate change scenar-

\footnotetext{
* Corresponding author. Tel.: +4942121865665.

E-mail address: wbrocas@marum.de (W.M. Brocas).
}

ios (Yin and Berger, 2010). Although the primary driver of climatic change differs, the LIG remains an important test bed for climate sensitivity studies within a warmer than present day earth system (Lunt et al., 2013). The LIG was punctuated by profound changes and instabilities. However, as demonstrated by a water hosing experiment performed on model simulations of LIG climate and a coral proxy record (Felis et al., 2015), temperature seasonality in the tropical Atlantic was relatively insensitive to the influences of monumental ice sheet loss (Blanchon et al., 2009), sea level rise (O'Leary et al., 2013), rapid reorganisation of oceanic currents (Galaasen et al., 2014), cold events (Mokeddem et al., 2014) and abrupt climatic shifts (Sirocko et al., 2005).

Tropical Atlantic climate variability plays a significant role in large-scale climate patterns and although much is known of its modern variability, the implication of past changes to this system 


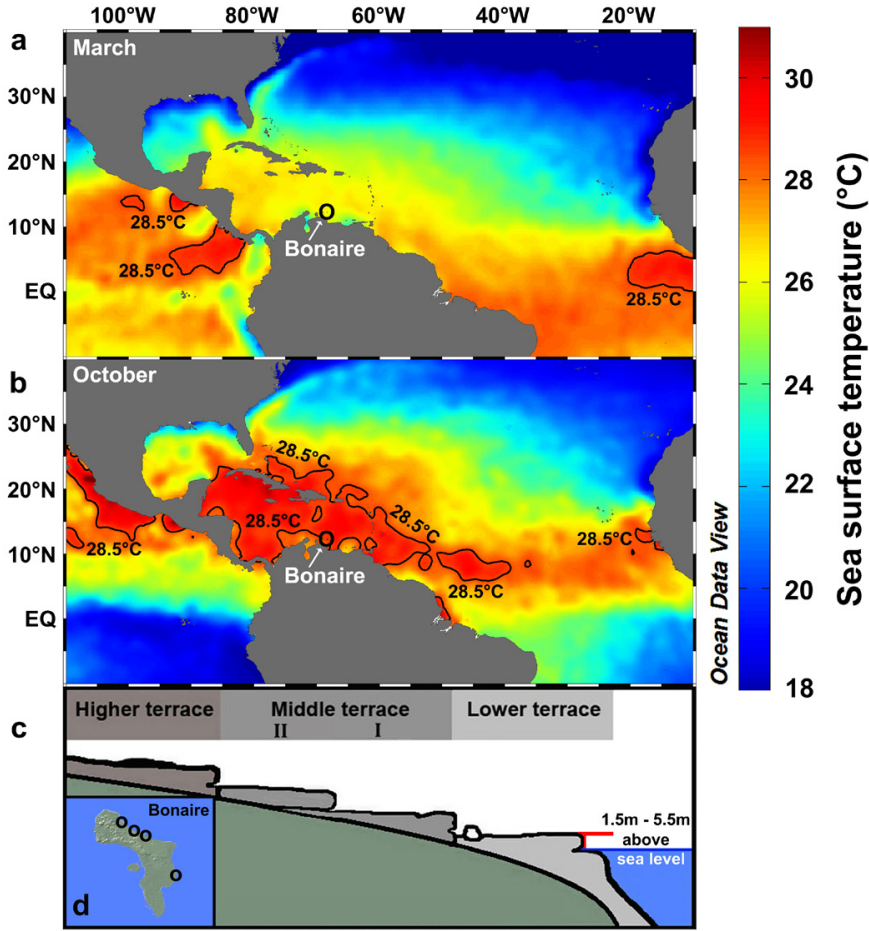

Fig. 1. Environmental setting of fossil Bonaire corals (circle). Tropical Atlantic sea surface temperatures (Locarnini et al., 2013) representing the coolest month, March (a), and the warmest, October (b), at Bonaire. The Atlantic warm pool is denoted by SST contours of greater than $28.5^{\circ} \mathrm{C}$. (c) Adapted geological schematic of elevated reef terraces along the coastline of Bonaire (Kim and Lee, 1999). The corals used in this study were recovered from 4 sites on the lower terrace (d) that formed during the last interglacial period (Felis et al., 2015; Obert et al., 2016). (The reader is referred to the online version of this article for full colour reference and interpretation.)

requires further study. In the Caribbean basin, sea surface temperature (SST) variability is a result of variations in North Atlantic sea level pressure that modulates surface winds and induces fluctuation to the Atlantic Warm Pool (AWP). The AWP is characterised by surface waters warmer than $28.5^{\circ} \mathrm{C}$ located in the tropical Atlantic (Fig. 1) and experiences fluctuations on seasonal, interannual and multidecadal time scales (Wang et al., 2008). On these latter two time scales, the El Niño-Southern Oscillation (ENSO) and the Atlantic Multidecadal Oscillation (AMO) perturb the AWP, respectively. The climate of the tropical Atlantic is determined by the maximum extent to which the AWP penetrates during boreal summer. Fluctuations in hurricane activity and Nordeste (Brazil) and Sahel rainfall originate from within the tropical Atlantic region. This region is at the crossroads of multiple modes of variability that derive from the tropical and extratropical oceans (Czaja, 2004) where a dominant upwelling system, trade winds and currents preside (Jury, 2009). SST and regional rainfall patterns therefore express behaviours related to these influences and are of broad interest due to their association with decadal shifts in Caribbean socio-economic output (Jury, 2009). However, the effect of projected climate change on such modes/trends in SST variability remains uncertain.

Coral archives, when supplemented by reliable ${ }^{230} \mathrm{Th} / \mathrm{U}$ ages, can contribute seasonally resolved time windows for the assessment of past tropical climate variability. LIG Pacific Porites corals have characterised ENSO variability (Hughen et al., 1999; Tudhope et al., 2001) Termination II (McCulloch et al., 1999) and modulations to the Kuroshio Current (Suzuki et al., 2001). The latter two studies reported similar to and increased western Pacific SST seasonality, respectively, compared with modern for their periods of study within the LIG. Increased LIG SST seasonality has been re- ported in the northern Red Sea from a 122 ka coral and accredited primarily to enhanced winter cooling as a result of a tendency towards a more positive state of the North Atlantic Oscillation (NAO) at that time (Felis et al., 2004). Representation of tropical Atlantic SST seasonality during the LIG is so far limited to two coral studies from the Caribbean. A 4-year strontium/calcium ( $\mathrm{Sr} / \mathrm{Ca}$ ) Montastraea faveolata record from 127 ka recorded SST seasonality $1{ }^{\circ} \mathrm{C}$ higher than present (Winter et al., 2003), while a 20-year Diploria strigosa $\mathrm{Sr} / \mathrm{Ca}$ record at the end of the LIG (118 ka) reconstructed SST seasonality within the present-day range (Felis et al., 2015). Prior to the LIG, three Porites sp. coral studies explored SST seasonality during interglacial periods at different South Pacific islands. During MIS 7 at $197 \mathrm{ka}$, SST seasonality was reported as identical to modern (Asami et al., 2013). Likewise, during MIS 9 (337-374 ka), SST seasonality was found to be similar to modern (Kilbourne et al., 2004) and enhanced by up to 15\% (Ayling et al., 2006), respectively. These studies attribute orbital configuration influencing regional insolation as the primary mechanism behind the observed tropical SST variability. However all these studies draw their conclusions from a single coral based time window during their respective interglacials.

Here we assess past tropical Atlantic climate variability by quantifying the range of SST seasonality and identifying modes of SST variability during several coral-based time windows throughout the LIG. We implement $\mathrm{Sr} / \mathrm{Ca}$ palaeothermometry on precisely dated fossil specimens of $D$. strigosa corals that inhabited the shallow tropical waters of the southern Caribbean island of Bonaire (Caribbean Netherlands). The annually banded aragonite skeleton of $D$. strigosa is suitable for precision microsampling techniques (Hetzinger et al., 2006, 2010; Giry et al., 2010, 2012, 2013; Felis et al., 2015). Coral $\mathrm{Sr} / \mathrm{Ca}$ variations are a well-established proxy for SST variability on seasonal (Gagan et al., 1998), interannual (Felis et al., 2009) and multidecadal time scales (Linsley et al., 2000). The reconstruction of $\mathrm{Sr} / \mathrm{Ca}$-based SST seasonality is not affected by glacial/interglacial changes in the $\mathrm{Sr}$ content of seawater as a result of dissolution of shelf carbonates during glacial sea level low stands nor its residence time, which is on the order of millions of years (Stoll et al., 1999). These concerns typically affect reconstructions of absolute SST on these time scales (Kilbourne et al., 2004; Asami et al., 2013; Felis et al., 2012, 2014). Sr/Ca variations within $D$. strigosa have been successfully demonstrated to replicate Caribbean instrumental temperature trends during the past century (Hetzinger et al., 2006, 2010), highlighting the importance of site specific modern day records for the interpretation of palaeoclimatic reconstructions. Our study benefits from being able to assess SST variability based on D. strigosa coral $\mathrm{Sr} / \mathrm{Ca}$ records from Bonaire (southern Caribbean) in the context of the modern day, the midto late Holocene (Giry et al., 2012, 2013) and the end of LIG (Felis et al., 2015). Our well preserved coral material allows further explorations of the factors affecting tropical Atlantic SST variability for multiple occasions throughout the LIG.

\section{Material and methods}

\subsection{Study area and environmental setting}

The island of Bonaire $\left(\sim 12^{\circ} 10^{\prime} \mathrm{N}, 68^{\circ} 18^{\prime} \mathrm{W}\right)$ is situated $\sim 100 \mathrm{~km}$ off the north coast of Venezuela in the open ocean setting of the Lesser Antilles island arc, southern Caribbean Sea (Fig. 1). Bonaire is characterised by a semi-arid climate, receiving less than $\sim 550 \mathrm{~mm} / \mathrm{yr}$, while easterly trade winds predominate. These trade winds are commonly referred to as the Caribbean low level jet and vary in close connection with the North Atlantic subtropical high. Seasonal SST varies between a mean winter (February/March) minimum of $25.8 \pm 0.6$ and a mean summer (September/October) 
maximum of $28.3 \pm 0.5^{\circ} \mathrm{C}$ ( \pm 1 standard deviation) throughout the years 1910-2000 (ERSSTv3b, Smith et al., 2008).

\subsection{Coral material}

Cores from 32 fossil Diploria strigosa colonies were drilled during expeditions in 2006 and 2009 on top of an elevated reef terrace along the north-eastern and eastern coast of Bonaire (Caribbean Netherlands, Fig. 1d). Coral material was obtained between $\sim 1.5$ and $\sim 5.5 \mathrm{~m}$ above present sea level and between $\sim 20$ and $\sim 88 \mathrm{~m}$ from the present-day sea cliff edge. This conforms to the lower terrace described by Kim and Lee (1999) (Fig. 1c), which formed during the LIG (Felis et al., 2015; Obert et al., 2016). This feature typifies much of the northern and eastern coastline of Bonaire. Drilled coral cores were visually inspected and sectioned parallel to growth direction, as determined from the orientation of corallites. Thin cross sections (slabs) of 6-7 $\mathrm{mm}$ were sliced, which exposed the internal structures of each colony. Thus, it was possible to target the path of microsampling directly parallel to growth. Seven colonies were selected based on their suitability to produce the longest and most reliable geochemical records, while reflecting the broad geographical range of material retrieved from Bonaire. This study followed established procedures outlined by Felis et al. (2009), Giry et al. (2010, 2012).

\subsection{Screening for diagenesis}

Coral slabs were initially subjected to X-radiography in order to establish the presence of clearly identifiable density banding. This also acts as a preliminary indicator of preservation and aids the assessment of skeletal theca elements suitable for directing microsampling paths. X-radiography also serves to highlight regions within the coral slab to be avoided due to abnormally high or low density that likely results from diagenetic alteration. The dense theca skeletal element has been previously identified as the most suitable target source within D. strigosa for yielding $\mathrm{Sr} / \mathrm{Ca}$ records (Hetzinger et al., 2006; Giry et al., 2010). Once the target theca was identified within each of the seven selected colonies, parallel sections of mixed coralline skeletal elements were screened for preservation. Firstly, to quantify the calcite content of the aragonite skeleton, samples were finely ground and subjected to powder $\mathrm{X}$-ray diffraction analysis (powder XRD). Petrographic thin sections assessed under transmitted and cross/polarised light visualised any secondary aragonite or calcite cements.

\subsection{Microsampling, Sr/Ca analysis, chronology building and spectral analyses}

Visual slab surface inspection and indications from X-radiographs of coralline density allowed for the identification of theca skeletal wall elements that had suitable orientation to maximise the yield of coral powder microsampling. An estimate of average coral growth rates was made with further reference to the annual density bands seen in the X-radiographs. Based on these rates, continuous microsampling paths of either 0.4 or $0.5 \mathrm{~mm}$ interval spacing along the theca were used to ensure that approximately twelve samples were obtained per year, in accordance with established procedures (Giry et al., 2010, 2012; Felis et al., 2015). These sampling paths were created using a $0.6 \mathrm{~mm}$ diameter drill bit along the centre of the theca, to a depth of $2 \mathrm{~mm}$. Subsequent geochemical analysis, visual inspection and additional $\mathrm{X}$-radiographs confirmed that the sampling path had been precise. This ensured that the targeted theca has been milled and contamination from adjacent skeletal elements had been avoided. Approximately $0.30-0.35 \mathrm{mg}$ of the milled coral powder was collected, weighed and dissolved in $4.0 \mathrm{ml}$ of $2 \%$ suprapure $\mathrm{HNO}_{3}$ containing
$1 \mathrm{ppm}$ Scandium. Coral Sr/Ca measurements were performed using an ICP-OES at MARUM (University of Bremen). Offline corrections for instrumental drift were accounted for after each sample using a laboratory coral standard. Analysed identically to our samples, 74 sub-samples of coral powder reference material JCp-1 (Hathorne et al., 2013) were measured, and the average $\mathrm{Sr} / \mathrm{Ca}$ value was $8.902 \pm 0.020 \mathrm{mmol} / \mathrm{mol}$. Only $\mathrm{Sr} / \mathrm{Ca}$ measurements with $\leq 0.2 \%$ relative standard deviation were assessed further.

$\mathrm{Sr} / \mathrm{Ca}$ records were assigned age models based on X-radiograph inferred annual density banding and annual cycling of $\mathrm{Sr} / \mathrm{Ca}$ seen in the records themselves. With the support of our climate modelling simulations, we determined that the timing of the maximum (September/October) and minimum (February/March) annual SST cycle did not change during the last interglacial (LIG) from that seen in present day SST records (Smith et al., 2008). Annual maximum and minimum $\mathrm{Sr} / \mathrm{Ca}$ values were therefore assigned as tie-points to the coldest (February/March) and warmest (September/October) months, respectively. Monthly time series were generated by following the established procedures of Felis et al. (2009) and Giry et al. (2010). Thereby, a monthly time series of Sr/Ca results from linear interpolation between these tie-points and subsequent interpolation to monthly resolution. Annual skeletal growth rates were determined by taking the distance between the maximum $\mathrm{Sr} / \mathrm{Ca}$ values of each individual year, to that of the next. The average of all years on record resulted in the mean coral growth rate.

Within any given year, the $\mathrm{Sr} / \mathrm{Ca}$ seasonality was calculated by subtracting the maximum (coldest) from the minimum (warmest) monthly value, from the oldest toward the youngest part of the record. The average of all years on record resulted in the mean $\mathrm{Sr} / \mathrm{Ca}$ seasonality value, which was then converted to SST seasonality using the seasonal $\mathrm{Sr} / \mathrm{Ca}-\mathrm{SST}$ relationship of $-0.042 \mathrm{mmol} / \mathrm{mol}$ per ${ }^{\circ} \mathrm{C}$ for $D$. strigosa (Hetzinger et al., 2006). Recent studies have supported the close range of Caribbean D. strigosa monthly $\mathrm{Sr} / \mathrm{Ca}-$ SST calibration slopes, reporting values of -0.040 (von Reumont et al., 2016) and -0.046 (Xu et al., 2015) $\mathrm{mmol} / \mathrm{mol} /{ }^{\circ} \mathrm{C}$. We employed the Hetzinger et al. (2006) calibration because it derives from amongst the longest modern $D$. strigosa record and its use closely replicates the instrumental SST seasonality at Bonaire (ERSSTv3b; Smith et al., 2008), as demonstrated by Giry et al. (2012) using three modern D. strigosa colonies.

Multitaper method spectral analysis (Ghil et al., 2002) was applied to the detrended and normalised monthly interpolated (with the mean annual cycle removed) and seasonally collated (boreal winter: Dec-Feb; spring: Mar-May; summer: Jun-Jul; autumn: Sep-Nov) coral $\mathrm{Sr} / \mathrm{Ca}$ records. Significance relative to a red noise null hypothesis was established using a robust method of noise background estimation (Mann and Lees, 1996) (three tapers; bandwidth parameter two).

\subsection{Coral $^{230} \mathrm{Th} / \mathrm{U}$ dating}

${ }^{230} \mathrm{Th} / \mathrm{U}$-ages of our coral colonies were determined using precise ${ }^{230} \mathrm{Th} / \mathrm{U}$-dating at the Max Planck Institute for Chemistry, Mainz, Germany (Obert et al., 2016). Here, we only briefly summarise this study. Several sub-samples of each coral were taken for ${ }^{230} \mathrm{Th} / \mathrm{U}$-dating using a Nu Plasma multi-collector inductively coupled plasma mass spectrometer (MC-ICPMS). Some sub-samples were comprised of mixed coralline structures, which is typical for this type of analysis, while others consisted only of the dense theca element. These dense theca wall samples are generally better preserved, show less evidence for post-depositional diagenetic alteration and provide more reliable ages (Obert et al., 2016). Here, the following six criteria were used to assess the reliability of coral ages. 
Table 1

Details of the coral $\mathrm{Sr} / \mathrm{Ca}$ records employed in this study.

\begin{tabular}{|c|c|c|c|c|c|c|c|c|c|}
\hline Sample I.D. & $\begin{array}{l}\text { No. of ages } \\
\text { (Bulk }+ \\
\text { Theca) }\end{array}$ & $\begin{array}{l}\text { Age }^{a} \\
(\mathrm{ka})\end{array}$ & $\begin{array}{l}\text { Standard de- } \\
\text { viation/error }{ }^{\mathrm{a}} \\
( \pm 2 \text { s.d./s.e.) } \\
(\mathrm{ka})\end{array}$ & $\begin{array}{l}\text { Calcite } \\
\text { content }^{\mathrm{b}} \\
(\%)\end{array}$ & $\begin{array}{l}\text { Annual } \\
\text { growth rate } \\
(\mathrm{cm} / \mathrm{yr}) \\
( \pm 1 \text { s.d. })\end{array}$ & $\begin{array}{l}\text { Sampling } \\
\text { resolution } \\
\text { (samples/yr) } \\
( \pm 1 \text { s.d.) }\end{array}$ & $\begin{array}{l}\text { Record length } \\
(\mathrm{yr})\end{array}$ & $\begin{array}{l}\mathrm{Sr} / \mathrm{Ca} \\
\text { seasonality } \\
(\mathrm{mmol} / \mathrm{mol}) \\
( \pm 1 \text { s.e. })\end{array}$ & $\begin{array}{l}\mathrm{Sr} / \mathrm{Ca}-\mathrm{SST}^{\mathrm{c}} \\
\text { seasonality } \\
\left({ }^{\circ} \mathrm{C}\right) \\
( \pm 1 \text { s.e. }) \\
( \pm 1 \text { c.e. })\end{array}$ \\
\hline BON-5-D* & $1(1+0)$ & 117.7 & 0.8 & $<1 \%$ & $0.68(0.15)$ & $11(2)$ & 20 & $0.109(0.003)$ & $2.6(0.1)(0.8)$ \\
\hline BON-5-A & $6(2+4)$ & 120.5 & 1.1 & $\leq 1 \%$ & $0.48(0.10)$ & $15(3)$ & 14 & $0.129(0.011)$ & $3.1(0.3)(0.8)$ \\
\hline BON-28-AI & $2(0+2)$ & $123.3^{* * *}$ & $3.1^{* * *}$ & $\leq 1 \%$ & $0.84(0.29)$ & $17(5)$ & 6 & $0.128(0.013)$ & $3.0(0.3)(0.9)$ \\
\hline BON-12-A & $4(2+2)$ & 123.9 & 1.3 & $\leq 1 \%$ & $0.60(0.15)$ & $13(3)$ & 37 & $0.172(0.008)$ & $4.1(0.2)(0.8)$ \\
\hline BON-26-A & $2(0+2)$ & 124.9 & 1.9 & $\leq 1 \%$ & $0.63(0.08)$ & $13(1)$ & 3 & $0.139(0.016)$ & $3.3(0.4)(0.9)$ \\
\hline BON-24-AII.2 & $3(1+2)$ & 125.5 & 2.4 & $\leq 2 \%$ & $0.62(0.07)$ & $14(2)$ & 5 & $0.139(0.019)$ & $3.3(0.5)(0.9)$ \\
\hline BON-13-AI.1 & $1(0+1)$ & 125.8 & 1.6 & $\leq 1 \%$ & $0.74(0.17)$ & $16(5)$ & 10 & $0.205(0.023)$ & $4.9(0.5)(1.0)$ \\
\hline BON-33-BI.2 & $1(0+1)$ & $129.7^{* *}$ & $1.7^{* *}$ & $\leq 1 \%$ & $0.71(0.24)$ & $13(5)$ & 10 & $0.128(0.015)$ & $3.0(0.4)(0.9)$ \\
\hline
\end{tabular}

* A previously published late last interglacial coral form Bonaire (Felis et al., 2015).

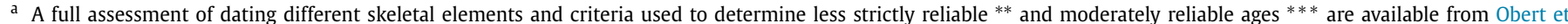

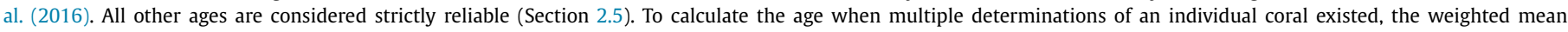
and weighted standard error of the sub-samples was used.

b Powder X-ray diffraction to quantify the calcite content of the coral material.

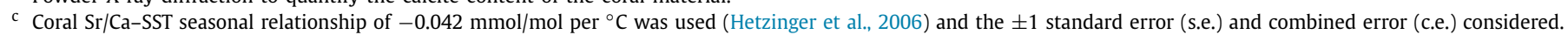

Table 2

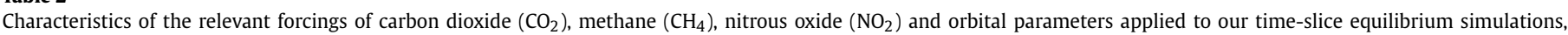

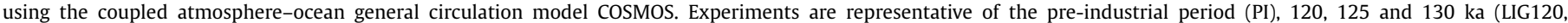
LIG125 and LIG130, respectively). The extent of ice sheets is fixed to that of the pre-industrial period.

\begin{tabular}{|c|c|c|c|c|c|c|}
\hline Experiment & $\begin{array}{l}\mathrm{CO}_{2} \\
(\mathrm{ppm})\end{array}$ & $\begin{array}{l}\mathrm{CH}_{4} \\
(\mathrm{ppb})\end{array}$ & $\begin{array}{l}\mathrm{NO}_{2} \\
(\mathrm{ppb})\end{array}$ & Eccentricity & Obliquity & Precession \\
\hline PI & 280 & 760 & 270 & 0.017 & 23.446 & 282.040 \\
\hline LIG120 & 268 & 261 & 261 & 0.041 & 22.998 & 209.040 \\
\hline LIG125 & 276 & 263 & 263 & 0.040 & 23.790 & 127.140 \\
\hline LIG130 & 257 & 238 & 238 & 0.038 & 24.246 & 48.320 \\
\hline
\end{tabular}

- The existence of primary aragonitic textures

- Calcite content $\leq 2 \%$

- ${ }^{238} \mathrm{U}$ concentration within the range of the respective modern coral species

- $<1 \mathrm{ng} \mathrm{g}^{-1}{ }^{232}$ Th content

- $\left({ }^{234} \mathrm{U} /{ }^{238} \mathrm{U}\right)_{i}=1.1468 \pm 0.004$

- Different sub-samples of the same coral have ${ }^{230} \mathrm{Th} / \mathrm{U}$-ages and activity ratios in agreement within error

${ }^{230} \mathrm{Th} / \mathrm{U}$-ages are considered as "strictly reliable" if all criteria are fulfilled, "less strictly reliable" if the initial $\left({ }^{234} U /{ }^{238} U\right)$ activity ratio is within $1.1468 \pm 0.008$, as opposed to \pm 0.004 , and "moderately reliable" if the ${ }^{232} \mathrm{Th}$ content was also larger than $1 \mathrm{ngg}^{-1}$ (Obert et al., 2016). For multiple determinations of an individual coral, we use the weighted mean and weighted standard error of the sub-samples to calculate the age (Table 1). All ages are presented as thousand years ago (ka) before the year of measurement (AD 2014). Uncertainties are quoted at the $2 \sigma$-level.

\subsection{Climate model set-up and experimentation}

We performed numerical simulations using the coupled general atmosphere-ocean circulation model COSMOS developed originally at the Max Planck Institute for Meteorology, Hamburg, Germany. COSMOS (Jungclaus et al., 2010) is comprised of an atmospheric model ECHAM5, an ocean model MPIOM, and a dynamical vegetation model JSBACH. Further details underpinning the models incorporated into COSMOS can be found in Stepanek and Lohmann (2012) and Felis et al. (2015). Orbital and greenhouse gas parameters identical to those used in the Paleoclimate Modelling Intercomparison Project (Table 2) are employed and values evaluated after a spin up of 2500 years. We conduct four equilibrium simulations using 100 pre-industrial and 400 LIG years to evaluate modelled North Atlantic SST seasonality during the pre-industrial,
120,125 and $130 \mathrm{ka}$ for a $1^{\circ} \times 1^{\circ}$ gridbox centred at $12.5^{\circ} \mathrm{N}$, $68^{\circ} \mathrm{W}$. These time-slice experiments supplement COSMOS transient simulations of the LIG SST seasonality utilised in Felis et al. (2015).

\section{Results}

\subsection{Skeletal preservation of fossil Diploria strigosa corals}

Clear and distinct density banding patterns are observed within the X-radiographs of our seven fossil coral colonies (Fig. 2c) and are comparable to the annual density-band pairs reported for modern, mid- to late Holocene and late LIG D. strigosa corals from Bonaire (Giry et al., 2012; Felis et al., 2015). The X-radiographs indicate that regions of abnormal skeletal density, which typify areas of diagenetic alteration, were avoided. Powder XRD analysis of bulk skeletal material defined the calcite content of six of our seven fossil colonies to be $\leq 1 \%$ (Table 1 ). BON-24-AII.2 contained $\leq 2 \%$ calcite, which is within acceptable levels for the purposes of our investigations and consistent with other LIG coral palaeoclimatic studies (Felis et al., 2004). Representative thin section images (Fig. 2a-b) revealed that the majority of skeletal elements were free of secondary aragonite cement. On the rare occasion that these were noted, they were found to exist in the porous septa and collumellae skeletal elements of the coralline structure and not the theca from which geochemical sampling was targeted. Therefore, we consider our corals well preserved and suitable for palaeoclimatic reconstructions.

\subsection{Coral $^{230} \mathrm{Th} / \mathrm{U}$ ages}

Following the reliability criteria established by Obert et al. (2016), five of the seven corals have strictly reliable ages (Table 1). Although passing all other criteria, the age of coral colony BON-33-BI.2 age is deemed "less strictly reliable" as the age 

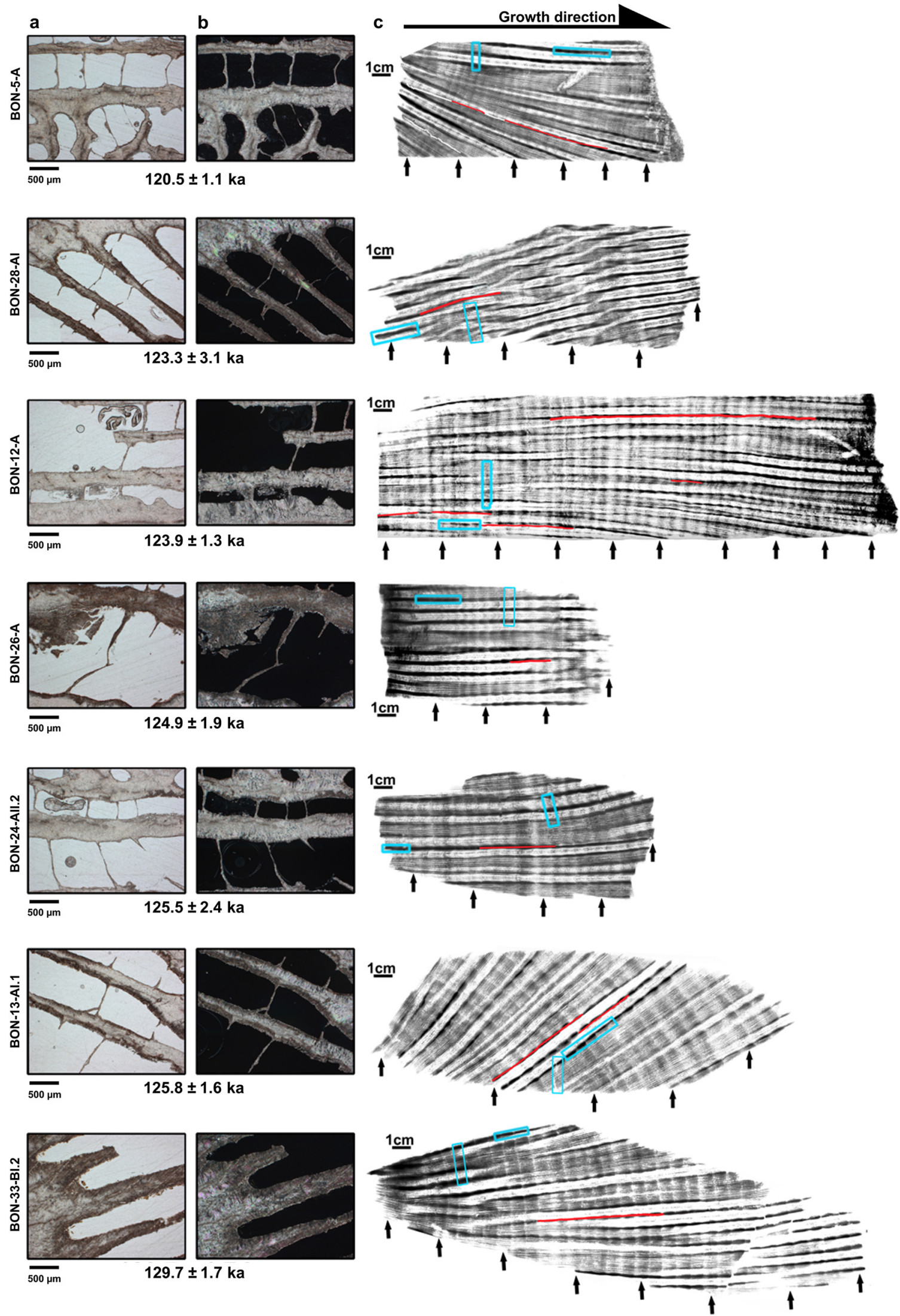

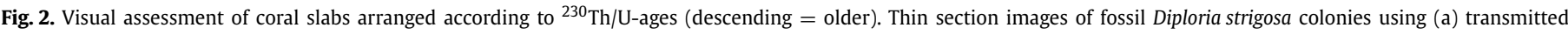

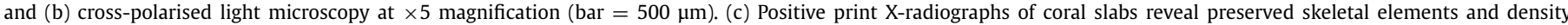

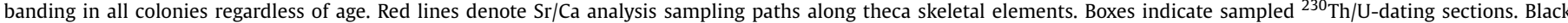

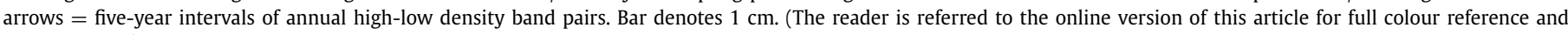
interpretation.) 

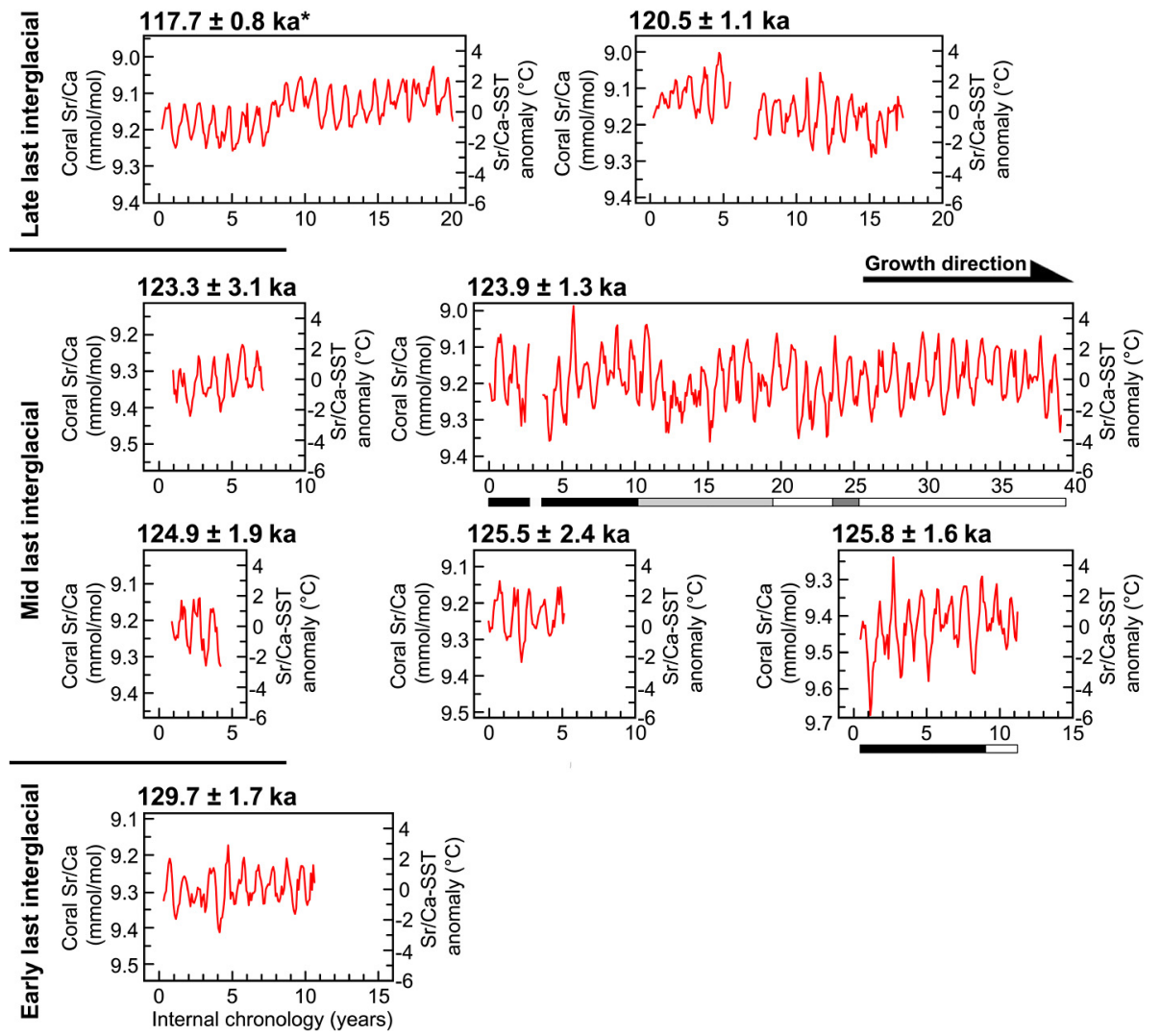

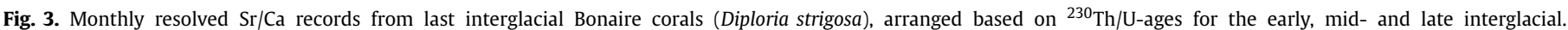

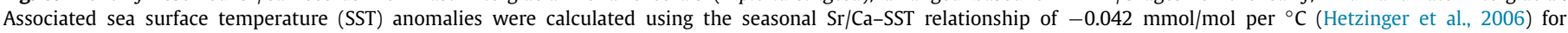

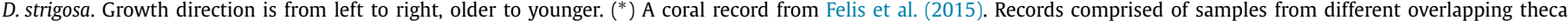

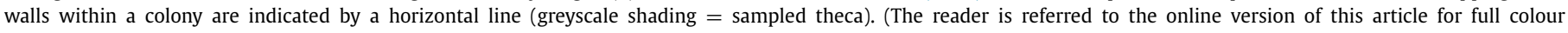
reference and interpretation.)

has an $\left({ }^{234} \mathrm{U} /{ }^{238} \mathrm{U}\right)$ activity ratio equal to 1.1468 within \pm 0.008 rather than \pm 0.004 . In addition, the two ages determined for BON-28-A showed a ${ }^{232} \mathrm{Th}$ content $\geq 1 \mathrm{ngg}^{-1}$. Thus, we consider the age of this sample "moderately reliable". The majority of ${ }^{230} \mathrm{Th} / \mathrm{U}$-ages cluster around peak LIG conditions (123.3 \pm 3.1 , $123.9 \pm 1.3,124.9 \pm 1.9,125.5 \pm 2.4,125.8 \pm 1.6 \mathrm{ka})$ while BON-5-A and BON-33-BI.2 grew during the late $(120.5 \pm 1.1 \mathrm{ka})$ and early $(129.7 \pm 1.7 \mathrm{ka})$ LIG, respectively. Thus our coral $\mathrm{Sr} / \mathrm{Ca}$ records reflect a broad range of time intervals throughout the LIG.

\subsection{Coral Sr/Ca derived SST time windows during the LIG}

Throughout the LIG, we present 85 years of monthly resolved $\mathrm{Sr} / \mathrm{Ca}$ records from seven fossil corals, representing time windows of between 3 and 37 years (Fig. 3). In addition, we make use of a previously published 20 year monthly coral $\mathrm{Sr} / \mathrm{Ca}$ record from Bonaire $(117.7 \pm 0.8 \mathrm{ka}$ ) (Felis et al., 2015). Annual cycles within the $\mathrm{Sr} / \mathrm{Ca}$ records are distinct and correspond to the annual density pattern observed in the X-radiographs. Robust internal chronologies were established that facilitate the interpretation of LIG seasonal to interannual SST variability. The details underpinning the $\mathrm{Sr} / \mathrm{Ca}$ records can be found in Table 1 . Within our $\mathrm{Sr} / \mathrm{Ca}$ records that comprise of sampling from multiple theca wall elements within the same colony (BON-12-A and BON-13-A1.1) we detect no anomalous shifts in mean $\mathrm{Sr} / \mathrm{Ca}$ or reconstructed SST seasonality. Although relationships between growth rates and $\mathrm{Sr} / \mathrm{Ca}$ ratios have been suggested for other coral species (Goodkin et al., 2007), we found no correlation between D. strigosa growth rates and annual mean $\mathrm{Sr} / \mathrm{Ca}$ or $\mathrm{Sr} / \mathrm{Ca}$ seasonality values.

\subsection{Coral Sr/Ca seasonality throughout the LIG}

Mean modern instrumental seasonality of SST surrounding Bonaire is $2.9 \pm 0.5^{\circ} \mathrm{C}( \pm 1$ standard deviation, s.d., $1910-2000)$ (Smith et al., 2008). Employing the seasonal Sr/Ca-SST relationship of $-0.042 \mathrm{mmol} / \mathrm{mol}$ per ${ }^{\circ} \mathrm{C}$ for $D$. strigosa (Hetzinger et al., 2006), this has been successfully reconstructed using three modern $D$. strigosa colonies from Bonaire, which recorded mean SST seasonality as $2.8 \pm 0.4{ }^{\circ} \mathrm{C}$ ( \pm 1 s.d.) (Giry et al., 2012). The use of other monthly $\mathrm{Sr} / \mathrm{Ca}-\mathrm{SST}$ calibration slopes (Giry et al., 2012; Xu et al., 2015; von Reumont et al., 2016) alters mainly the absolute amplitude of reconstructed SST seasonality but has only minor effects on the relative SST seasonality estimates exhibited by our specific corals. We note that modern coral-based SST seasonality ranges from $2.4 \pm 0.3$ to $3.0 \pm 0.3^{\circ} \mathrm{C}$ ( \pm 1 standard error, s.e.), reflecting intercolony differences, which are not associated with different sampling resolutions, growth rates or real differences in SST seasonality over the last century. Consequently, our $\mathrm{Sr} / \mathrm{Ca}$ derived LIG SST seasonality reconstructions implement the s.e. of an individual fossil coral. Although it's not possible to identify the exact palaeo-reef environment (fore or back reef) each coral grew within, we find no evidence such as anomalous growth within our LIG records, which would be indicative of the influence of different reef environments (water depths) on SST seasonality. To address this uncertainty we additionally consider the combined error (c.e.) of Abram et al. (2009) which incorporates differences between the reconstructed mean SST seasonality from three modern Bonaire corals (Giry et al., 2012). The c.e. is derived from the combination (root of the sum of the squares) of 1) the standard deviation (2 s.d.) of the reconstructed mean $\mathrm{Sr} / \mathrm{Ca}$ seasonality value from three modern corals and 2) the standard error (2 s.e.) surround- 


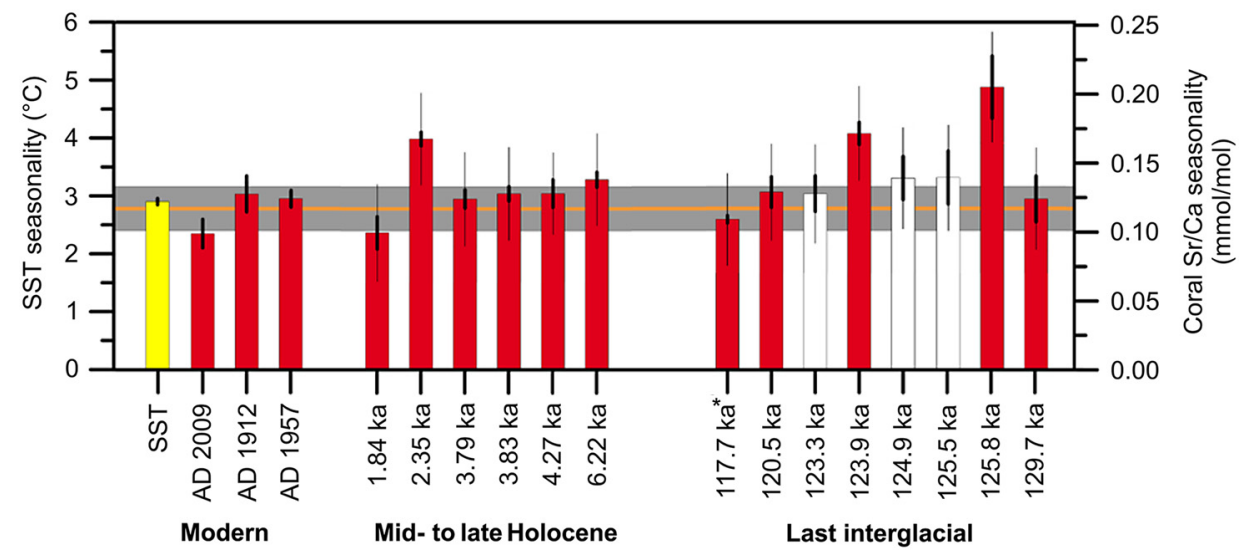

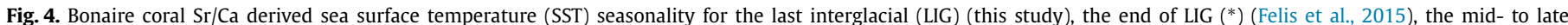

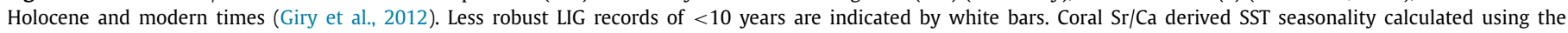

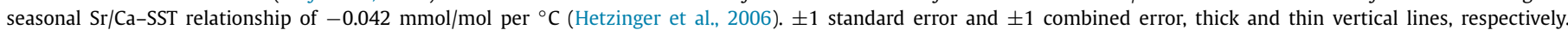

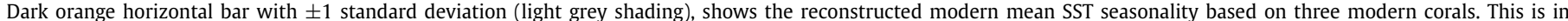

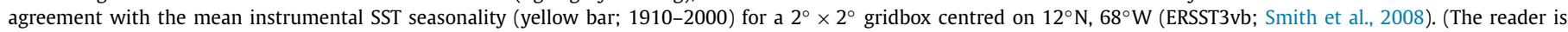
referred to the online version of this article for full colour reference and interpretation.)

ing the mean of all $\mathrm{Sr} / \mathrm{Ca}$ seasonality on record within each fossil coral. We examine the individual coral errors relative to the s.d. of $\mathrm{Sr} / \mathrm{Ca}-\mathrm{SST}$ seasonality from the three modern corals. The details underpinning our coral $\mathrm{Sr} / \mathrm{Ca}$ records (Table 1 ) are consistent with those reported by Giry et al. (2012) and other LIG coral records (Felis et al., 2004, 2015).

Compared to the modern coral reconstructed mean SST seasonality of $2.8 \pm 0.4{ }^{\circ} \mathrm{C}$ ( \pm 1 s.d.) (Fig. 4), we find that our oldest coral at $129.7 \pm 1.7 \mathrm{ka}$ records a similar seasonality of $3.0 \pm 0.4^{\circ} \mathrm{C}$ ( \pm 1 s.e.) during the early LIG. Three of five mid-LIG corals, which contain $\leq 6$ years, record a similar to modern SST seasonality of $3.3 \pm 0.5^{\circ} \mathrm{C}$ ( \pm 1 s.e.), $3.3 \pm 0.4{ }^{\circ} \mathrm{C}( \pm 1$ s.e. $)$ and $3.0 \pm 0.3^{\circ} \mathrm{C}$ ( \pm 1 s.e.) at $125.5 \pm 2.4,124.9 \pm 1.9$ and $123.3 \pm 3.1 \mathrm{ka}$, respectively. However, two coral records at $125.8 \pm 1.6$ and $123.9 \pm 1.3 \mathrm{ka}$, which contain $\geq 10$ years and are considered to be more robust, record significantly higher than modern SST seasonality of $4.9 \pm 0.5( \pm 1$ s.e.) and $4.1 \pm 0.2{ }^{\circ} \mathrm{C}( \pm 1$ s.e. $)$, respectively. The former value is the highest SST seasonality observed in any of the Bonaire coral time windows. Towards the end of LIG, SST seasonality is found to reduce to $3.1 \pm 0.3{ }^{\circ} \mathrm{C}$ ( \pm 1 s.e.) and $2.6 \pm 0.1^{\circ} \mathrm{C}$ ( \pm 1 s.e.) at $120.5 \pm 1.1 \mathrm{ka}$ and $117.7 \pm 0.8 \mathrm{ka}$, respectively. These late LIG SST seasonality values are similar to modern day.

Without fossil coral records spanning several decades or more, questions regarding our ability to capture and interpret climate evolution during the LIG arise (e.g., Kilbourne et al., 2004). For instance, to what extent can a snapshot of SST seasonality from a coral $\mathrm{Sr} / \mathrm{Ca}$ time window represent a mean climatic state during the LIG, rather than a short-term excursion? Indeed, within a time window of less than 20 years, how might a single year dominate the interpreted seasonality signal? In order to address these questions, we focus on our two coral time windows that reflect higher than present day seasonality (Fig. 4). Firstly, our most robust record of LIG SST variations comprises of 37 annual cycles from $123.9 \pm 1.3 \mathrm{ka}$. The record of annual seasonality was detrended, and running averages (windows) of various lengths were analysed relative to the standard error ( \pm 1 s.e. and \pm 2 s.e.) of the entire record to create hypothetical shorter records of different lengths. Any averaged value within a running window that exceeds the standard error envelope ( \pm 2 s.e.) does not fully represent the seasonality expressed by the entire coral record. We thus consider a record of that length to be more easily influenced by short-term (interannual) excursions in reconstructed SST seasonality. Fig. 5 illustrates that any given running window of $<$ ten years has a value that exceeds \pm 2 s.e. of the entire $123.9 \pm 1.3 \mathrm{ka}$

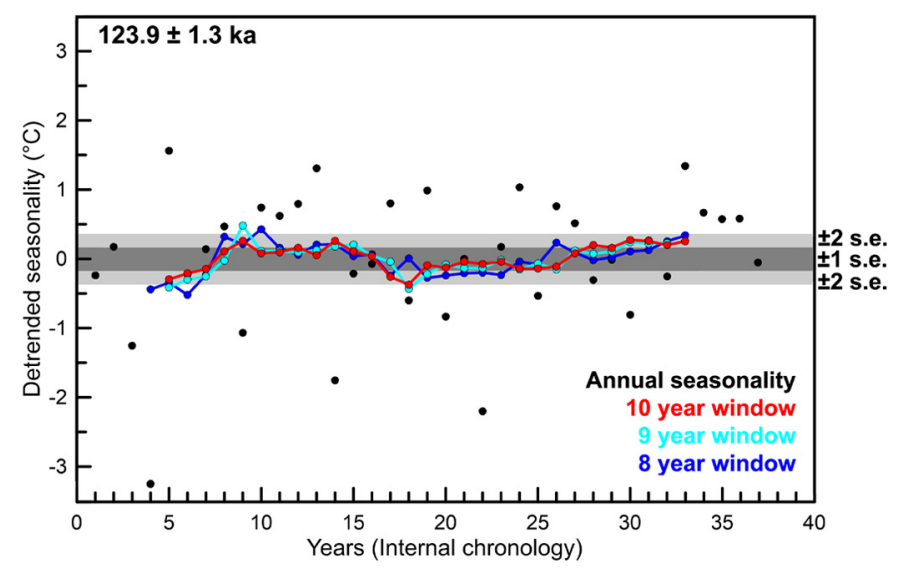

Fig. 5. Detrended annual sea surface temperature seasonality record for $123.9 \pm$ $1.3 \mathrm{ka}$ (black dots). Running windows of length averaging ten (red), nine (light blue) and eight years (dark blue). \pm 1 (dark grey) and 2 (light grey) standard error envelopes from the record mean are displayed. (The reader is referred to the online version of this article for full colour reference and interpretation.)

record and therefore should be considered unrepresentative. Although this approach is only appropriate to use within this specific record and only for $D$. strigosa corals, it lends support to the rationale behind excluding our $123.3 \pm 3.1,124.9 \pm 1.9$ and $125.5 \pm 2.4$ ka records. These records depict SST seasonality similar to modern values while being of $\leq$ six years in length (Fig. 4, denoted by white bars). The moderately reliable age obtained for our $123.3 \pm 3.1$ ka coral further adds doubt to the interpretation of this record. Our $125.8 \pm 1.6 \mathrm{ka}$ record of maximum SST seasonality is supported despite being 10 years in length. Although close examination of this record reveals no reason to do so, randomly excluding the SST seasonality of any year from this record reduces the SST seasonality such that the \pm s.e. overlaps with our other mid-LIG record (123.9 ka). Importantly, the mean SST seasonality of our $125.8 \pm 1.6$ ka record remains above that $( \pm 1$ s.e. and c.e.) of the modern average. In summary, the remaining four robust records (at 120.5, 123.9, 125.8 and $129.7 \mathrm{ka}$ ), plus the previously published coral from 117.7 ka (Felis et al., 2015), are used to reconstruct the evolution of SST seasonality throughout the LIG. Two of which (123.9 and $125.8 \mathrm{ka}$ ) express SST seasonality significantly higher than modern values during the midLIG. 
Time-slice equilibrium simulations of pre-industrial, 120, 125 and $130 \mathrm{ka}$ SST seasonality using the coupled atmosphereocean general circulation model COSMOS depict a similartrend of $3.5 \pm 0.7^{\circ} \mathrm{C}, 3.9 \pm 0.7^{\circ} \mathrm{C}, 5.8 \pm 1.0^{\circ} \mathrm{C}$ and $4.9 \pm 0.9^{\circ} \mathrm{C}( \pm 1$ s.d.) (Fig. 6b), respectively. These results are in agreement with the composite coral Sr/Ca derived SST seasonality for $\sim 120$ and $\sim 125 \mathrm{ka}$, and indicate that these are representative of the wider tropical and North Atlantic region (Fig. 7). Furthermore, our timeslice simulations demonstrate that enhanced mid-LIG SST seasonality in the tropical Atlantic, as indicated by the Bonaire coral $\mathrm{Sr} / \mathrm{Ca}$ records, was primarily the result of summer warming (Fig. 6c).

\subsection{Coral Sr/Ca-SST variability at $124 \mathrm{ka}$}

Of the eight presented coral Sr/Ca records only that of $123.9 \pm$ $1.3 \mathrm{ka}$, from the mid-LIG, is of sufficient length to potentially capture interannual to decadal modes of SST variability (Fig. 3). From the 35 continuous years (of 37 years) of this monthly resolved record, we detected quasi-biennial SST variability at 2.7 years with 99\% confidence and decadal SST variability at 12.2 years with 95\% confidence (Fig. 8). Seasonal decomposition of the record reveals that quasi-biennial (2.6 years) SST variability is significant at 95\% during December-February (DJF) and June-August (JJA), but is most significant at 99\% during March-May (MAM). Quasi-decadal (8.7 years) and decadal (12.3 years) SST variability is only significant (95\%) within the DJF record.

\section{Discussion}

Prior to this study, LIG tropical Atlantic SST seasonality had been characterised by four years of $\mathrm{Sr} / \mathrm{Ca}$ derived SST from a 127 ka aged Montastraea faveolata coral from the Isla de Mona, north-eastern Caribbean (Winter et al., 2003), and 20 years (Felis et al., 2015) from a 118 ka aged Diploria strigosa coral from Bonaire. These two single snapshot studies, the first from the mid and the second from the late LIG, report SST seasonality as having been enhanced by $1{ }^{\circ} \mathrm{C}$ compared to the present day and within the modern range, respectively. By reconstructing a comprehensive evolution of tropical Atlantic SST seasonality throughout the LIG, we support and build on these two studies that attributed the role of orbital controls on the seasonal insolation cycle as the primary driver of tropical SST seasonality from a single last interglacial time window. Our reconstructed peak SST seasonality of $4.9 \pm 0.5^{\circ} \mathrm{C}$ ( \pm 1 s.e.) at $125.8 \mathrm{ka}$, in conjunction with our $123.9 \mathrm{ka}$ record $\left(4.1 \pm 0.2^{\circ} \mathrm{C}\right)$, reconstructs mean SST seasonality higher than modern $\left(2.8 \pm 0.4^{\circ} \mathrm{C}, \pm 1\right.$ s.d.) and likely reflects a period of peak SST seasonality within the Caribbean during the LIG. This assessment is further supported when the combined error is considered (Fig. 4 and Fig. 6). The combined error (Abram et al., 2009) incorporates modern day intercolony differences and thus reflects the potential uncertainties in the $\mathrm{Sr} / \mathrm{Ca}-\mathrm{SST}$ calibration, location, water depth (reef habitats) and time intervals associated with differing $\mathrm{Sr} / \mathrm{Ca}-$ SST seasonality reconstructed from three modern corals (Giry et al., 2012). Although our records of $\leq 6$ years window length are unlikely to fully represent SST seasonality for their respective LIG time period, they do provide insights into coral based SST reconstructions. BON-28-A (Table 1) (123.3 ka) has a moderately reliable age with relatively large uncertainty $( \pm 3.1 \mathrm{ka})$, which can potentially place it into the late-LIG for which its reconstructed SST seasonality of $3.0^{\circ} \mathrm{C}$ would be plausible. BON-26-A (124.9 ka) and BON-24-AII.2 (125.5 ka) record SST seasonality marginally higher but within error of modern day values. These records illustrate the high degree of variability in reconstructed mid-LIG seasonality and thus the importance of long and continuous records.

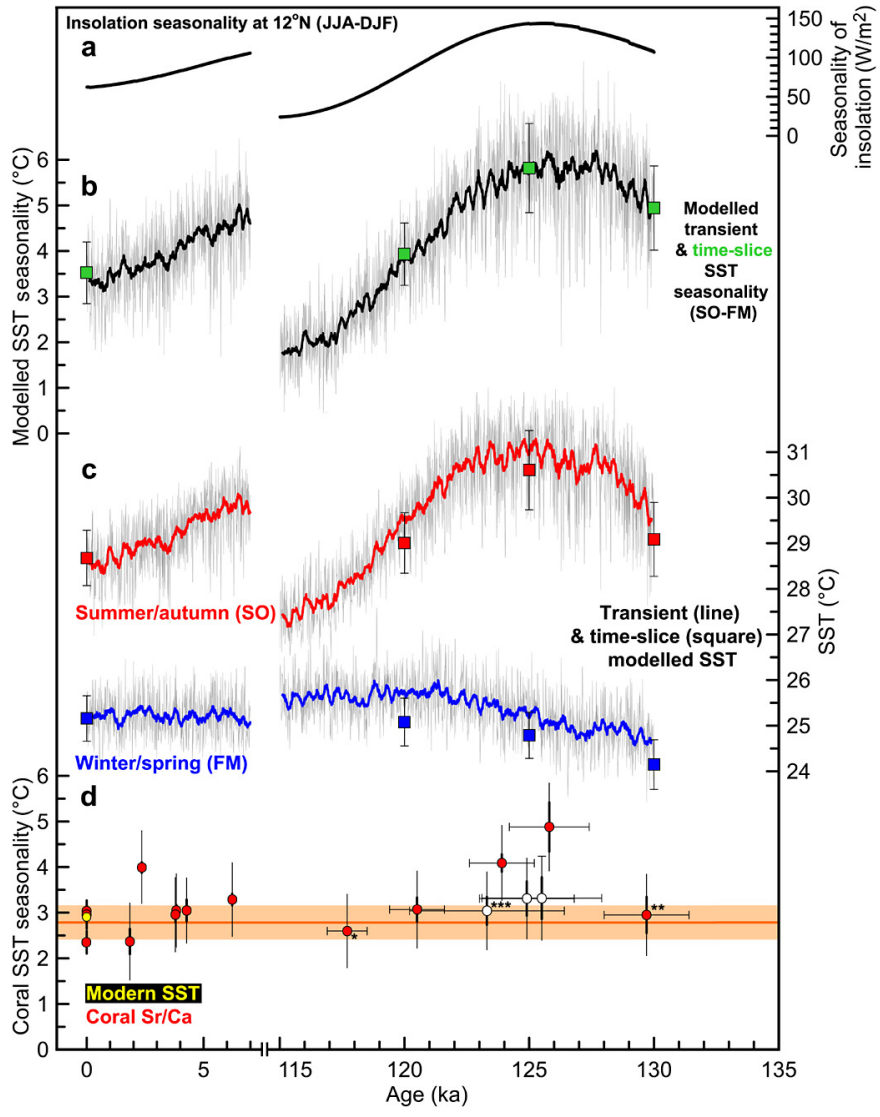

Fig. 6. Bonaire coral- and model-based sea surface temperature (SST) seasonality throughout the last interglacial (LIG). (a) Seasonality of insolation (June-JulyAugust, JJA minus December-January-February, DJF) at the latitude of Bonaire $\left(12^{\circ} \mathrm{N}\right)$ (Berger, 1978). (b) Transient (Felis et al., 2015) and time-slice (squares) simulations of SST seasonality (September-October, SO minus February-March, FM) around Bonaire $\left(1^{\circ} \times 1^{\circ}\right.$ gridbox centred at $\left.12.5^{\circ} \mathrm{N}, 68^{\circ} \mathrm{W}\right)$ using the coupledatmosphere-ocean general circulation model COSMOS. (c) Transient and time-slice (squares) simulations of Bonaire summer/autumn (SO) and winter/spring (FM) SST. Thick lines (b,c) represents a 21-point running average of the transient simulation (representing an average of 210 calendar years) and vertical lines around squares represent the \pm 1 standard deviation (s.d.) of the time-slice simulations. (d) Modern and mid- to late Holocene (Giry et al., 2012), end of LIG (*, Felis et al., 2015) and LIG coral Sr/Ca derived SST seasonality for Bonaire $( \pm 1$ standard error $=$ thick vertical lines, \pm 1 combined error $=$ thin vertical lines. The three modern corals mean is represented by an orange line with \pm 1 s.d. (light orange shading) and agrees with modern instrumental SST seasonality (1910-2000, ERSSTv3b; Smith et al., 2008). Coral $\mathrm{Sr} / \mathrm{Ca}$ derived SST seasonality calculated using the seasonal $\mathrm{Sr} / \mathrm{Ca}$-SST relationship of $-0.042 \mathrm{mmol} / \mathrm{mol}$ per ${ }^{\circ} \mathrm{C}$ (Hetzinger et al., 2006). White dots denote records of $<$ ten years length. All LIG coral ages are considered strictly reliable (Obert et al., 2016) (Section 2.5), aside from a less strictly reliable $\left(^{* *}\right)$ and a moderately reliable $\left({ }^{* *}\right)$ age. ${ }^{230} \mathrm{Th} / \mathrm{U}$-age uncertainty is reported at $2 \sigma$ level. (The reader is referred to the online version of this article for full colour reference and interpretation.)

\subsection{Forcings on SST seasonality during the LIG}

In the Northern Hemisphere, the annual cycle of insolation was significantly more pronounced during the LIG as a result of an enhanced precession cycle, driven by higher obliquity and eccentricity. This coincided with the occurrence of the perihelion in boreal summer (Yin and Berger, 2010). Such an orbital configuration induced stronger seasonal amplitudes of insolation at the latitude of Bonaire $\left(12^{\circ} \mathrm{N}\right)$ during the LIG (Fig. 6a). In addition to the previously published coral at 117.7 ka (Felis et al., 2015), the $\mathrm{Sr} / \mathrm{Ca}$ derived SST seasonality from four of our seven new coral time windows, which we consider to be the more robust records (at 120.5, 123.9, 125.8 and $129.7 \mathrm{ka}$ ), follow the evolving seasonal cycle of insolation during the LIG (Fig. 6a). The significantly higher than present-day SST seasonality at 125.8 and $123.9 \mathrm{ka}$ are in the midst of the LIG and consistent with peak seasonality of in- 


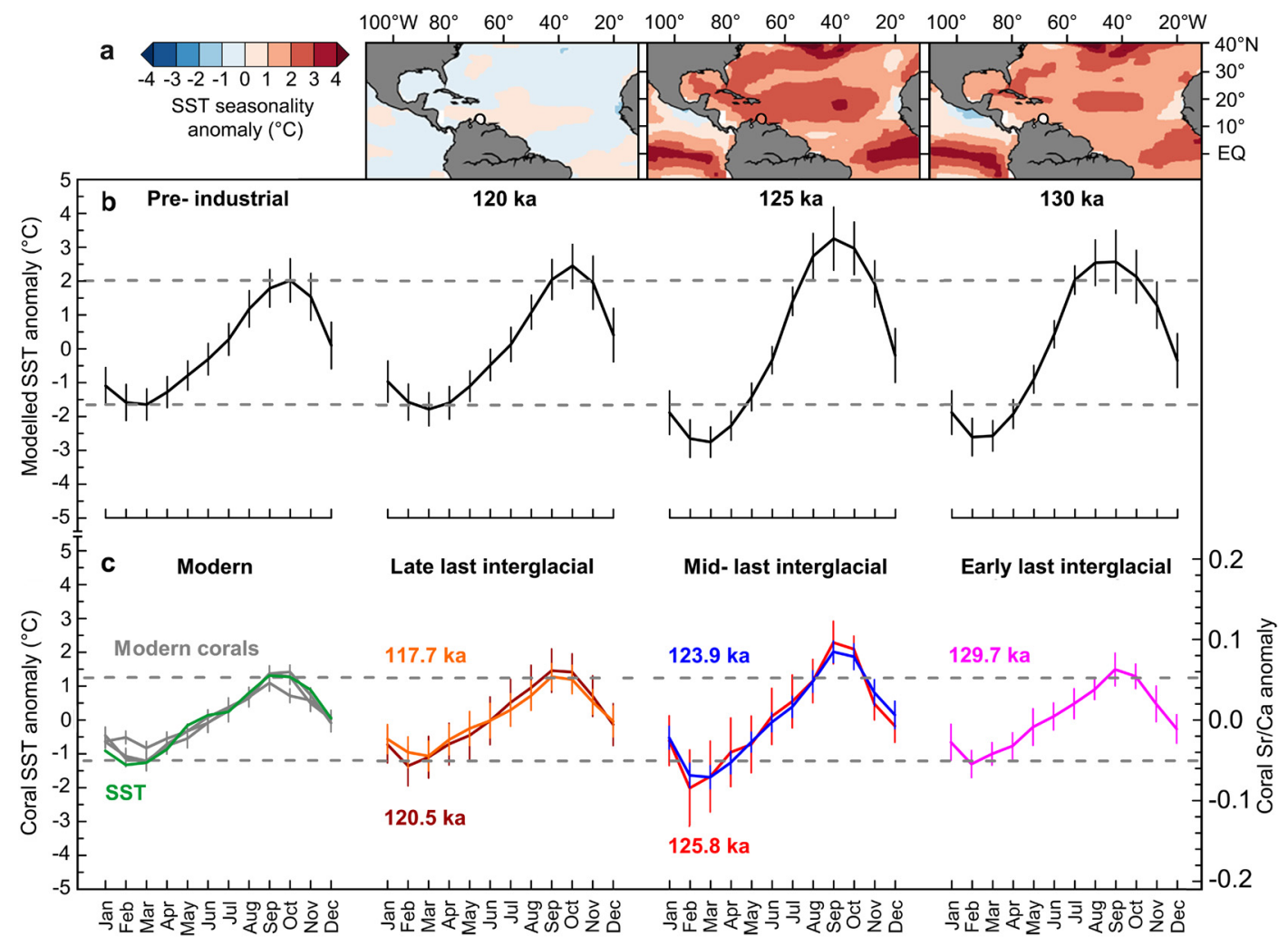

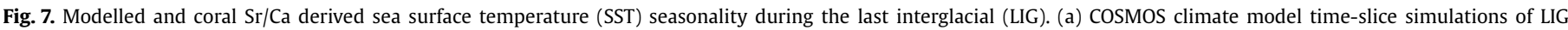

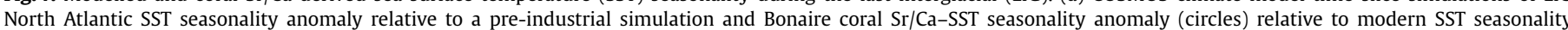

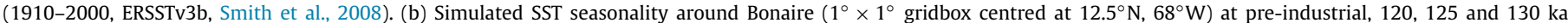

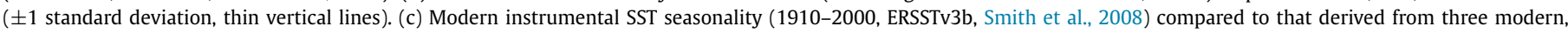

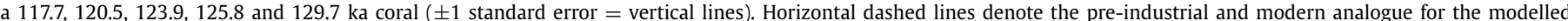

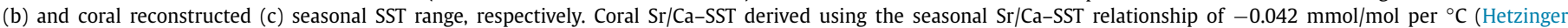

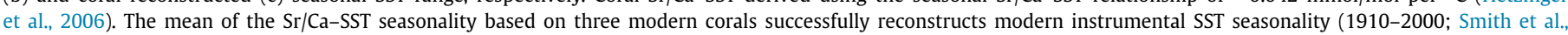
2008). (The reader is referred to the online version of this article for full colour reference and interpretation.)

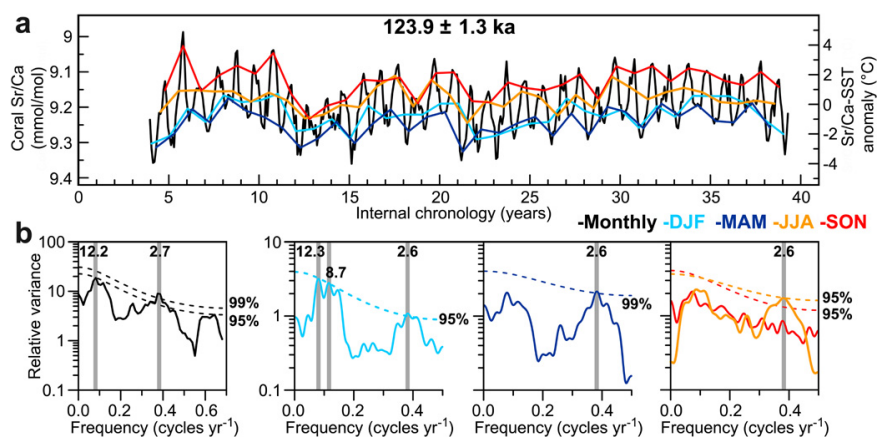

Fig. 8. Multi-taper spectral analysis of a 35-year monthly resolved coral $\mathrm{Sr} / \mathrm{Ca}$ proxy record of sea surface temperature (SST) from 124 ka ago. (a) Monthly and seasonally-decomposed time series representing boreal winter (December-JanuaryFebruary, DJF), spring (March-April-May, MAM), summer (June-July-August, JJA) and autumn (September-October-November, SON). Associated SST anomaly derived using a seasonal coral $\mathrm{Sr} / \mathrm{Ca}$-relationship of $-0.042 \mathrm{mmol} / \mathrm{mol}$ per ${ }^{\circ} \mathrm{C}$ for Diploria strigosa (Hetzinger et al., 2006). (b) Multitaper method spectral analysis implementing a red noise null hypothesis (Ghil et al., 2002) on detrended and normalised monthly (with averaged seasonal cycle removed) and seasonally collated time series. $95 \%$ and $99 \%$ confidence limits are shown. Vertical grey bars highlight significant periodicities. (The reader is referred to the online version of this article for full colour reference and interpretation.)

solation at $\sim 125.5 \mathrm{ka}$ (Berger, 1978). The coupled SST-insolation seasonality trend we describe throughout the LIG is similar to the trend observed during the mid- to late Holocene. During the latter period, a notable exception to this trend identified in a $2.3 \mathrm{ka}$ coral is interpreted to reflect a time interval of strengthened ENSO teleconnections to the Caribbean region (Giry et al., 2012;
Felis et al., 2015). Importantly however, this does not necessarily imply a strengthening of the ENSO phenomenon in the tropical Pacific at that time (Felis et al., 2015).

Likewise, our climate model (COSMOS) time-slice simulations and the transient simulations (Felis et al., 2015) of LIG SST seasonality are consistent with the coral based results (Fig. 6). Fig. 7a illustrates this modelled SST seasonality trend as representative for the Caribbean and large areas of the tropical North Atlantic. In comparison with the coral records that cluster around 120 and $125 \mathrm{ka}$, modelled SST seasonality is higher by $\sim 1$ to $2^{\circ} \mathrm{C}$, while at $130 \mathrm{ka}, \mathrm{a} \sim 2{ }^{\circ} \mathrm{C}$ higher seasonality was found. These results are broadly consistent with a $\sim 0.6^{\circ} \mathrm{C}$ higher seasonality of the modelled pre-industrial SST compared to the instrumental record (ERSSTv3b; 1910-2000) which, importantly, is in agreement with the reconstructed modern mean coral $\mathrm{Sr} / \mathrm{Ca}$-SST seasonality (Fig. 6). Regardless of uncertainties surrounding ice sheet sensitivity and vegetation feedback during interglacials, the pre-industrial, 120 and 125 ka SST seasonality simulations are in agreement, within error ( \pm 1 s.d.), with their coral counterparts (Fig. 7). The deviation from the coral record at $130 \mathrm{ka}$ is likely a result of the model initialisation parameters being unrepresentative of this time. The continued influences of a rapid deglaciation event (Termination II) likely saw the presence of larger continental ice sheets and a reorganisation of North Atlantic oceanic currents around $130 \mathrm{ka}$ (Govin et al., 2012, and references therein). Of significance to this study is the evolving trend of SST seasonality throughout the LIG, which is similarly expressed by the coral reconstructions and climate model simulations. 
The advantage of the combined coral proxy and modelling approach presented here is the consistency of the results from our coral $\mathrm{Sr} / \mathrm{Ca}$ records, the time-slice simulations and the transient simulations of Felis et al. (2015). These modelling efforts reveal that the mid-LIG increased SST seasonality in the Caribbean Sea results primarily from summer warming, contrary to the conclusion reached in Winter et al. (2003). Our coral Sr/Ca records and time-slice simulations also further substantiate the transient modelling and hosing experiments (Felis et al., 2015) that demonstrate the insensitivity of tropical SST seasonality to the wider climate instabilities that perturbed the Atlantic realm during the LIG (Sirocko et al., 2005; Blanchon et al., 2009; O’Leary et al., 2013; Galaasen et al., 2014; Mokeddem et al., 2014). In summary, our results affirm the prevailing influence of orbital insolation changes on tropical SST seasonality.

Tropical Pacific SST seasonality has been demonstrated, using single coral time windows, to be in agreement with the orbital configuration influencing seasonality of insolation during MIS 7 (197 ka) (Asami et al., 2013) and MIS 9 (337-374 ka) (Kilbourne et al., 2004; Ayling et al., 2006). In conjunction with these studies, tropical SST seasonality during the last 3 interglacials is observably sensitive to the prevailing orbital configuration and resulting influence on the seasonality of insolation. Our multicoral approach allows us to demonstrate this for the LIG with greater certainty. Furthermore, multicoral reconstructions of the evolution of SST seasonality during the LIG contribute to efforts to chart the sequence of events that characterise the LIG, within well-defined age uncertainties (Govin et al., 2015). For instance, we reconstruct early LIG tropical Atlantic SST seasonality at 130 ka that is similar to modern, implying that modern day SST seasonality at Bonaire was reached relatively rapidly after the onset of the LIG following Termination II. However, tropical Atlantic corals which date to deglacial and glacial periods are required to further test such assertions.

\subsection{Spectral variability of SST at $123.9 \pm 1.3 \mathrm{ka}$}

We detect quasi-biennial (2.6-2.7 years) SST variability at $123.9 \mathrm{ka}$ in the monthly, summer (JJA), spring (MAM) and winter (DJF) coral Sr/Ca based SST records (Fig. 8b), which is in agreement with the modern instrumental SST record (Smith et al., 2008). These findings are in accordance with the quasi-biennial behaviour observed within Atlantic SST variability (Dima and Lohmann, 2004) and its influence on a similar quasi-biennial variance seen in tropical Atlantic hurricane activity (Gray, 1984). We also detect a quasidecadal SST variability of 8.7 years in our 123.9 ka winter record. However, although the underpinning mechanisms are poorly constrained, the NAO is thought to modulate this $\sim 8$ year mode by inducing fluctuations in the easterly trade winds and rainfall in the region of coastal Venezuela (Jury, 2009).

Despite the length of our 123.9 ka record being at the limit of detection of decadal variability, a decadal spectral peak of $\sim 12$ years is visually observable throughout all component series, but is only significant in the monthly and DJF SST time series (Fig. 8b). While being found in modern instrumental SST records (Deser and Blackmon, 1993) and the Cariaco basin sedimentary records spanning the past $\sim 800$ years (Black et al., 1999), our 123.9 ka coral record represents the first evidence of decadal SST variability in the tropical North Atlantic during the LIG. This decadal mode is indicative of the Atlantic SST anomaly tripole that influences basin wide air-sea heat fluxes and climatic patterns (Moron et al., 1998). The detection of these SST modes in the southern Caribbean during the LIG suggests a prevailing interconnection with the North Atlantic at that time, perhaps strengthened by orbital forcing. More studies involving multiple sub-annually resolved proxy records of SST are required to further assess the precise relationships between interannual to decadal modes of LIG climate variability and corresponding forcing mechanisms.

\section{Conclusions}

Utilising $\mathrm{Sr} / \mathrm{Ca}$ measurements of well dated and preserved fossil Diploria strigosa corals from the southern Caribbean island of Bonaire; we generated monthly resolved records that reconstruct SST seasonality and variability for various time windows throughout the LIG. These records, along with a previously published one (Felis et al., 2015), total 105 years in length and allow a unique assessment of tropical Atlantic SST seasonality and climate variability during the LIG. Relative to modern instrumental SST records and mid- to late Holocene and modern coral based SST reconstructions we make the following conclusions:

- Our monthly coral Sr/Ca derived SST proxy records reconstruct similar to modern SST seasonality of $\sim 2.9^{\circ} \mathrm{C}$ during the early (130 ka) and late LIG (120-118 ka) in the tropical North Atlantic Ocean. However, within the mid-LIG at $\sim 126 \mathrm{ka}$ and $\sim 124$ ka we find significantly higher than modern SST seasonality of 4.9 and $4.1^{\circ} \mathrm{C}$, respectively. The reconstructed evolution of SST seasonality is consistent with the evolving amplitude of orbitally induced changes in seasonality of insolation throughout the LIG. This demonstrates the dominance of orbitally controlled changes in the seasonality of insolation on the seasonality of tropical Atlantic SST during the LIG.

- Our climate model simulations are in agreement with the coral $\mathrm{Sr} / \mathrm{Ca}$ derived SST records of seasonality changes throughout the LIG as a result of orbital forcing and illustrate the representative nature of the reconstructed SST seasonality evolution between 118 and 130 ka for the tropical North Atlantic Ocean. Additionally, our model simulations indicate that reconstructed higher SST seasonality during the mid-LIG was primarily the result of warmer summers.

- In our longest coral record, 35 continuous years from $123.9 \mathrm{ka}$ during the mid-LIG, we detect modes of SST variability. A pattern of quasi-biennial (2.6-2.7 years) SST variability was in existence in the tropical North Atlantic during the mid-LIG. We also find evidence for quasi-decadal (8.7 years) and decadal $(\sim 12.2$ years) SST variability in the tropical North Atlantic during the mid-LIG. These modes of SST variability are similarly observed in modern instrumental records. Decadal variability is a fundamental feature of North Atlantic SST at the present day. We identify its persistence in this region during a period of the past characterised by warmer than modern conditions and differing orbital configurations.

- The LIG remains an important test-bed for our understanding of climate dynamics, and here we establish that alongside the range of estimates reported for how much warmer the LIG was than today, significant orbitally induced changes occurred in tropical SST seasonality. Recent studies have illustrated that the LIG was a period of notable climatic shifts and instabilities (Felis et al., 2015), however, tropical North Atlantic SST seasonality was relatively stable and evolved in tandem with orbitally driven seasonality of insolation. In light of future changes to climatic boundary conditions, our results point to the important role of orbital insolation forcing on tropical SST seasonality during interglacials warmer than today.

\section{Acknowledgements}

We thank the Government of the Island Territory of Bonaire of the former Netherlands Antilles (now Caribbean Netherlands) for research and fieldwork permissions, and E. Beukenboom (STINAPA Bonaire National Parks Foundation) for support. This study was 
funded by the Deutsche Forschungsgemeinschaft through grants FE 615/3-2, 3-4 to T.F., SCHO 1274/4-4 to D.S. and LO 895/9-4 to G.L. (DFG Priority Programme INTERDYNAMIK - SPP 1266), and FE 615/5-1 to T.F. J.C.O. and D.S. are thankful to K.P. Jochum and M.O. Andreae from the MPI for Chemistry, Mainz, as well as the Max Planck Graduate Center (MPGC) for financial support. J. Pätzold and C. Giry are thanked for field assistance, S. Pape for maintaining and operating of the ICP-OES, C. Vogt for powder X-ray diffraction analysis. G. Wefer, H. Kuhnert, A. Govin and K. DeLong are recognised for their contribution to discussions. T.F. is supported through the DFG-Research Center/Cluster of Excellence 'The Ocean in the Earth System' at the University of Bremen. W.B. acknowledges support from GLOMAR (Bremen International Graduate School for Marine Sciences).

\section{References}

Abram, N.J., McGregor, H.V., Gagan, M.K., Hantoro, W.S., Suwargadi, B.W., 2009. Oscillations in the southern extent of the Indo-Pacific Warm Pool during the mid-Holocene. Quat. Sci. Rev. 28 (25-26), 2794-2803. http://dx.doi.org/10.1016/ j.quascirev.2009.07.006

Asami, R., Iryu, Y., Hanawa, K., Miwa, T., Holden, P., Shinjo, R., Paulay, G., 2013. MIS 7 interglacial sea-surface temperature and salinity reconstructions from a southwestern subtropical Pacific coral. Quat. Res. 80 (3), 575-585. http://dx.doi.org/ 10.1016/j.yqres.2013.09.002.

Ayling, B.F., McCulloch, M.T., Gagan, M.K., Stirling, C.H., Andersen, M.B., Blake, S.G., 2006. $\mathrm{Sr} / \mathrm{Ca}$ and $\delta^{18} \mathrm{O}$ seasonality in a Porites coral from the MIS 9 (339-303 ka) interglacial. Earth Planet. Sci. Lett. 248 (1), 462-475. http://dx.doi.org/10.1016/ j.epsl.2006.06.009.

Berger, A.L., 1978. Long-term variations of caloric insolation resulting from the Earth's orbital elements. Quat. Res. 9 (2), 139-167. http://dx.doi.org/10.1175/ 1520-0469(1978)035<2362:LTVODI >2.0.CO;2.

Black, D.E., Peterson, L.C., Overpeck, J.T., Kaplan, A., Evans, M.N., Kashgarian, M., 1999. Eight centuries of north Atlantic ocean atmosphere variability. Science 286 (5445), 1709-1713. http://dx.doi.org/10.1126/science.286.5445.1709.

Blanchon, P., Eisenhauer, A., Fietzke, J., Liebetrau, V., 2009. Rapid sea-level rise and reef back-stepping at the close of the last interglacial highstand. Nature 458 (7240), 881-884. http://dx.doi.org/10.1038/nature07933.

Braconnot, P., Harrison, S.P., Kageyama, M., Bartlein, P.J., Masson-Delmotte, V., AbeOuchi, A., Otto-Bliesner, B., Zhao, Y., 2012. Evaluation of climate models using palaeoclimatic data. Nat. Clim. Change 2 (6), 417-424. http://dx.doi.org/ 10.1038/NCLIMATE1456.

Czaja, A., 2004. Why is north tropical Atlantic SST variability stronger in Boreal spring? J. Climate 17 (15), 3017-3025. http://dx.doi.org/10.1175/ 1520-0442(2004)017<3017:WINTAS>2.0.CO;2.

Deser, C., Blackmon, M.L., 1993. Surface climate variations over the North Atlantic Ocean during winter: 1900-1989. J. Climate 6 (9), 1743-1753. http://dx.doi.org/ 10.1175/1520-0442(1993)006<1743: SCVOTN>2.0.CO;2.

Dima, M., Lohmann, G., 2004. Fundamental and derived modes of climate variability: concept and application to interannual time-scales. Tellus A 56 (3), 229-249. http://dx.doi.org/10.1111/j.1600-0870.2004.00059.x.

Felis, T., Lohmann, G., Kuhnert, H., Lorenz, S.J., Scholz, D., Pätzold, J., Al-Rousan, S.A Al-Moghrabi, S.M., 2004. Increased seasonality in Middle East temperatures during the last interglacial period. Nature 429 (6988), 164-168. http://dx.doi.org/ 10.1038 /nature02546.

Felis, T., Suzuki, A., Kuhnert, H., Dima, M., Lohmann, G., Kawahata, H., 2009. Subtropical coral reveals abrupt early-twentieth-century freshening in the western North Pacific Ocean. Geology 37 (6), 527-530. http://dx.doi.org/10.1130/ G25581A.1.

Felis, T., Merkel, U., Asami, R., Deschamps, P., Hathorne, E.C., Kölling, M., Bard, E., Cabioch, G., Durand, N., Prange, M., Schulz, M., Cahyarini, S.Y., Pfeiffer, M., 2012. Pronounced interannual variability in tropical South Pacific temperatures during Heinrich Stadial 1. Nat. Commun. 3, 965. http://dx.doi.org/10.1038/ncomms1973.

Felis, T., McGregor, H.V., Linsley, B.K., Tudhope, A.W., Gagan, M.K., Suzuki, A., Inoue, M., Thomas, A.L., Esat, T.M., Thompson, W.G., Tiwari, M., Potts, D.C., Mudelsee, M., Yokoyama, Y., Webster, J.M., 2014. Intensification of the meridional temperature gradient in the Great Barrier Reef following the Last Glacial Maximum. Nat. Commun. 5, 4102. http://dx.doi.org/10.1038/ncomms5102.

Felis, T., Giry, C., Scholz, D., Lohmann, G., Pfeiffer, M., Pätzold, J., Kölling, M., Scheffers, S.R., 2015. Tropical Atlantic temperature seasonality at the end of the last interglacial. Nat. Commun. 6, 6159. http://dx.doi.org/10.1038/ncomms7159.

Gagan, M.K., Ayliffe, L.K., Hopley, D., Cali, J.A., Mortimer, G.E., Chappell, J., McCulloch, M.T., Head, M.J., 1998. Temperature and surface-ocean water balance of the mid-holocene tropical western pacific. Science 279 (5353), 1014-1018. http:// dx.doi.org/10.1126/science.279.5353.1014.

Galaasen, E.V., Ninnemann, U.S., Irvali, N., Kleiven, H.F., Rosenthal, Y., Kissel, C., Hodell, D.A., 2014. Rapid reductions in North Atlantic deep water during the peak of the last interglacial period. Science 343 (6175), 1129-1132. http:// dx.doi.org/10.1126/science.1248667.

Ghil, M., Allen, M., Dettinger, M., Ide, K., Kondrashov, D., Mann, M., Robertson, A.W., Saunders, A., Tian, Y., Varadi, F., 2002. Advanced spectral methods for climatic time series. Rev. Geophys. 40 (1), 3-1-3-41. http://dx.doi.org/10.1029/ 2000RG000092.

Giry, C., Felis, T., Kölling, M., Scheffers, S., 2010. Geochemistry and skeletal structure of Diploria strigosa, implications for coral-based climate reconstruction. Palaeogeogr. Palaeoclimatol. Palaeoecol. 298 (3-4), 378-387. http://dx.doi.org/10.1016/ j.palaeo.2010.10.022.

Giry, C., Felis, T., Kölling, M., Scholz, D., Wei, W., Lohmann, G., Scheffers, S., 2012 Mid- to late Holocene changes in tropical Atlantic temperature seasonality and interannual to multidecadal variability documented in southern Caribbean corals. Earth Planet. Sci. Lett. 331-332, 187-200. http://dx.doi.org/10.1016/j.epsl. 2012.03.019.

Giry, C., Felis, T., Kölling, M., Wei, W., Lohmann, G., Scheffers, S., 2013. Controls of Caribbean surface hydrology during the mid- to late Holocene: insights from monthly resolved coral records. Clim. Past 9, 841-858. http://dx.doi.org/10.5194/ cp-9-841-2013.

Goodkin, N.F., Hughen, K.A., Cohen, A.L., 2007. A multicoral calibration method to approximate a universal equation relating $\mathrm{Sr} / \mathrm{Ca}$ and growth rate to sea surface temperature. Paleoceanography 22 (1). http://dx.doi.org/10.1029/2006PA001312.

Govin, A., Braconnot, P., Capron, E., Cortijo, E., Duplessy, J.-C., Jansen, E., Labeyrie, L., Landais, A., Marti, O., Michel, E., Mosquet, E., Risebrobakken, B., Swingedouw, D., Waelbroeck, C., 2012. Persistent influence of ice sheet melting on high northern latitude climate during the early Last Interglacial. Clim. Past 8, 483-507. http:// dx.doi.org/10.5194/cp-8-483-2012.

Govin, A., Capron, E., Tzedakis, P., Verheyden, S., Ghaleb, B., Hillaire-Marcel, C., StOnge, G., Stoner, J., Bassinot, F., Bazin, L., 2015. Sequence of events from the onset to the demise of the Last Interglacial: evaluating strengths and limitations of chronologies used in climatic archives. Quat. Sci. Rev. 129, 1-36. http:// dx.doi.org/10.1016/j.quascirev.2015.09.018.

Gray, W.M., 1984. Atlantic seasonal hurricane frequency. Part I: El Nino and $30 \mathrm{mb}$ quasi-biennial oscillation influences. Mon. Weather Rev. 112 (9), 1649-1668. http://dx.doi.org/10.1175/1520-0493(1984)112<1649:ASHFPI>2.0.CO;2.

Hathorne, E.C., Gagnon, A., Felis, T., Adkins, J., Asami, R., Boer, W., Caillon, N., Case D., Cobb, K.M., Douville, E., deMenocal, P., Eisenhauer, A., Garbe-Schönberg D., Geibert, W., Goldstein, S., Hughen, K., Inoue, M., Kawahata, H., Kölling, M. Cornec, F.L., Linsley, B.K., McGregor, H.V., Montagna, P., Nurhati, I.S., Quinn, T.M., Raddatz, J., Rebaubier, H., Robinson, L., Sadekov, A., Sherrell, R., Sinclair, D. Tudhope, A.W., Wei, G., Wong, H., Wu, H.C., You, C., 2013. Interlaboratory study for coral $\mathrm{Sr} / \mathrm{Ca}$ and other element/Ca ratio measurements. Geochem. Geophys. Geosyst. 14 (9), 3730-3750. http://dx.doi.org/10.1002/ggge.20230.

Hetzinger, S., Pfeiffer, M., Dullo, W., Ruprecht, E., Garbe-Schönberg, D., 2006. Sr/Ca and $\delta^{18} \mathrm{O}$ in a fast-growing Diploria strigosa coral: evaluation of a new climate archive for the tropical Atlantic. Geochem. Geophys. Geosyst. 7 (10), Q10002. http://dx.doi.org/10.1029/2006GC001347.

Hetzinger, S., Pfeiffer, M., Dullo, W., Garbe-Schönberg, D., Halfar, J., 2010. Rapid 20th century warming in the Caribbean and impact of remote forcing on climate in the northern tropical Atlantic as recorded in a Guadeloupe coral. Palaeogeogr. Palaeoclimatol. Palaeoecol. 296 (1-2), 111-124. http://dx.doi.org/10.1016/ j.palaeo.2010.06.019.

Hughen, K.A., Schrag, D.P., Jacobsen, S.B., Hantoro, W., 1999. El Niño during the Last Interglacial Period recorded by a fossil coral from Indonesia. Geophys. Res. Lett. 26 (20), 3129-3132. http://dx.doi.org/10.1029/1999GL006062.

Jungclaus, J., Lorenz, S., Timmreck, C., Reick, C., Brovkin, V., Six, K., Segschneider, J. Giorgetta, M., Crowley, T., Pongratz, J., 2010. Climate and carbon-cycle variability over the last millennium. Clim. Past 6, 723-737. http://dx.doi.org/10.5194/ cp-6-723-2010.

Jury, M.R., 2009. A quasi-decadal cycle in Caribbean climate. J. Geophys. Res., Atmos. 114, D13102. http://dx.doi.org/10.1029/2009JD011741, 1984-2012.

Kilbourne, K.H., Quinn, T.M., Taylor, F.W., 2004. A fossil coral perspective on western tropical Pacific climate $\sim 350$ ka. Paleoceanography 19 (1). http://dx.doi.org 10.1029/2003PA000944.

Kim, K.H., Lee, D.J., 1999. Distribution and depositional environments of coralline lithofacies in uplifted Pleistocene coral reefs of Bonaire, Netherlands Antilles. J. Korean Phys. Soc. 15 (2), 115-133.

Linsley, B.K., Wellington, G.M., Schrag, D.P., 2000. Decadal sea surface temperature variability in the subtropical South Pacific from 1726 to 1997 A.D. Science 290 (5494), 1145-1148. http://dx.doi.org/10.1126/science.290.5494.1145.

Locarnini, R.A., Mishonov, A.V., Antonov, J.I., Boyer, T.P., Garcia, H.E., Baranova, O.K., Zweng, M.M., Paver, C.R., Reagan, J.R., Johnson, D.R., Hamilton, M., Seidov, D., World Ocean Atlas 2013, in: Levitus, S. (Ed.), Mishonov, A. (Technical Ed.), Temperature, vol. 1. NOAA Atlas NESDIS 73, 40 pp.

Lunt, D.J., Abe-Ouchi, A., Bakker, P., Berger, A., Braconnot, P., Charbit, S., Fischer, N., Herold, N., Jungclaus, J.H., Khon, V.C., Krebs-Kanzow, U., Langebroek, P.M., Lohmann, G., Nisancioglu, K.H., Otto-Bliesner, B., Park, W., Pfeiffer, M., Phipps, S.J., Prange, M., Rachmayani, R., Renssen, H., Rosenbloom, N., Schneider, B., 
Stone, E.J., Takahashi, K., Wei, W., Yin, Q., Zhang, Z.S., 2013. A multi-model assessment of last interglacial temperatures. Clim. Past 9 (2), 699-717. http:// dx.doi.org/10.5194/cp-9-699-2013.

Mann, M.E., Lees, J.M., 1996. Robust estimation of background noise and signal detection in climatic time series. Clim. Change 33 (3), 409-445. http://dx.doi.org/ 10.1007/BF00142586.

McCulloch, M.T., Tudhope, A.W., Esat, T.M., Mortimer, G.E., Chappell, J., Pillans, B. Chivas, A.R., Omura, A., 1999. Coral record of equatorial sea-surface temperatures during the penultimate deglaciation at Huon Peninsula. Science 283 (5399), 202-204. http://dx.doi.org/10.1126/science.283.5399.202.

Mokeddem, Z., McManus, J.F., Oppo, D.W., 2014. Oceanographic dynamics and the end of the last interglacial in the subpolar North Atlantic. Proc. Natl. Acad. Sci. 111 (31), 11263-11268. http://dx.doi.org/10.1073/pnas.1322103111.

Moron, V., Vautard, R., Ghil, M., 1998. Trends, interdecadal and interannual oscillations in global sea-surface temperatures. Clim. Dyn. 14 (7-8), 545-569. http:/ dx.doi.org/10.1007/s003820050241.

Obert, J.C., Scholz, D., Felis, T., Brocas, W.M., Jochum, K.P., Andreae, M.O. 2016. ${ }^{230} \mathrm{Th} / \mathrm{U}$ dating of Last interglacial brain corals from Bonaire (southern Caribbean) using bulk and theca wall material. Geochim. Cosmochim. Acta 178, 20-40. http://dx.doi.org/10.1016/j.gca.2016.01.011.

O'Leary, M.J., Hearty, P.J., Thompson, W.G., Raymo, M.E., Mitrovica, J.X., Webster, J.M., 2013. Ice sheet collapse following a prolonged period of stable sea level during the last interglacial. Nat. Geosci. 6 (9), 796-800. http://dx.doi.org/ $10.1038 /$ ngeo 1890.

von Reumont, J., Hetzinger, S., Garbe-Schönberg, D., Manfrino, C., Dullo, W., 2016. Impact of warming events on reef-scale temperature variability as captured in two Little Cayman coral $\mathrm{Sr} / \mathrm{Ca}$ records. Geochem. Geophys. Geosyst. http:// dx.doi.org/10.1002/2015GC006194.

Sirocko, F., Seelos, K., Schaber, K., Rein, B., Dreher, F., Diehl, M., Lehne, R., Jäger, K., Krbetschek, M., Degering, D., 2005. A late Eemian aridity pulse in central Europe during the last glacial inception. Nature 436 (7052), 833-836. http://dx.doi.org/ 10.1038/nature03905.

Smith, T.M., Reynolds, R.W., Peterson, T.C., Lawrimore, J., 2008. Improvements to NOAA's historical merged land-ocean surface temperature analysis (1880-2006). J. Climate 21 (10), 2283-2296. http://dx.doi.org/10.1175/2007JCLI2100.1.

Stepanek, C., Lohmann, G., 2012. Modelling mid-Pliocene climate with COSMOS. Geosci. Model Dev. 5, 1221-1243. http://dx.doi.org/10.5194/gmd-5-1221-2012.

Stoll, H.M., Schrag, D.P., Clemens, S.C., 1999. Are seawater Sr/Ca variations preserved in Quaternary foraminifera? Geochim. Cosmochim. Acta 63 (21), 3535-3547. http://dx.doi.org/10.1016/S0016-7037(99)00129-5.

Suzuki, A., Gagan, M.K., De Deckker, P., Omura, A., Yukino, I., Kawahata, H., 2001. Last interglacial coral record of enhanced insolation seasonality and seawater ${ }^{18} \mathrm{O}$ enrichment in the Ryukyu Islands, northwest Pacific. Geophys. Res. Lett. 28 (19), 3685-3688. http://dx.doi.org/10.1029/2001GL013482.

Tudhope, A.W., Chilcott, C.P., McCulloch, M.T., Cook, E.R., Chappell, J., Ellam, R.M., Lea, D.W., Lough, J.M., Shimmield, G.B., 2001. Variability in the El Niño-Southern oscillation through a glacial-interglacial cycle. Science 291 (5508), 1511-1517. http://dx.doi.org/10.1126/science.1057969.

Wang, C., Lee, S., Enfield, D.B., 2008. Atlantic Warm Pool acting as a link between Atlantic Multidecadal Oscillation and Atlantic tropical cyclone activity. Geochem. Geophys. Geosyst. 9 (5), Q05V03. http://dx.doi.org/10.1029/2007GC001809.

Winter, A., Paul, A., Nyberg, J., Oba, T., Lundberg, J., Schrag, D., Taggart, B., 2003. Orbital control of low-latitude seasonality during the Eemian. Geophys. Res. Lett. 30 (4), 1163. http://dx.doi.org/10.1029/2002GL016275.

Xu, Y., Pearson, S., Kilbourne, K.H., 2015. Assessing coral Sr/Ca-SST calibration techniques using the species Diploria strigosa. Palaeogeogr. Palaeoclimatol. Palaeoecol. 440, 353-362. http://dx.doi.org/10.1016/j.palaeo.2015.09.016.

Yin, Q.Z., Berger, A., 2010. Insolation and $\mathrm{CO}_{2}$ contribution to the interglacial climate before and after the Mid-Brunhes Event. Nat. Geosci. 3 (4), 243-246. http:// dx.doi.org/10.1038/ngeo771. 